\title{
Kajian Potensi Limbah Kotoran Manusia Sebagai Pembangkit Listrik Tenaga Biogas Di Kota Pontianak
}

\author{
Ardiansyah \\ Magister Teknik Elektro Universitas Tanjungpura Pontianak \\ Pemerintah Kota Pontianak, Dinas Perhubungan Kota Pontianak \\ e-mail : the.ant01@gmail.com
}

\begin{abstract}
Utilization of human waste as a source of energy can produce methane gas through anaerobic digestion process, where the resulting methane gas is converted into electrical energy. In this research both electrical energy capacity and economics feasibility of Biogas Power Plant development from the utilization of human waste in Pontianak City calculated.

Based on the calculation and analysis of electrical energy capacity and economics feasibility, the potential of human waste in Pontianak City produces biogas of 3,091.94 $\mathrm{m}^{3} /$ day, methane gas 2,164,36 $\mathrm{m}^{3} /$ day, and electrical energy 24,157,88 $\mathrm{kWh} /$ day. The result of technical and economic analysis of energy conversion implementation using $250 \mathrm{~kW}$ microturbin produces electric power equal to 2,058,254,5 $\mathrm{kW}$ per year, pay back period 4 years 11 months, net present value 22,379.004.648 IDR, and internal rate of return of 18,681\%, so the construction of Biogas Power Plant is feasible to be implemented.
\end{abstract}

Keywords- anaerobic digestion, biogas, microturbine

\section{Pendahuluan}

Beberapa tahun terakhir ini energi merupakan persoalan yang krusial di dunia. Peningkatan permintaan energi yang disebabkan oleh pertumbuhan populasi penduduk dan menipisnya sumber cadangan minyak dunia serta permasalahan emisi dari bahan bakar fosil memberikan tekanan kepada setiap negara untuk segera memproduksi dan menggunakan energi yang dapat diperbaharui.

Untuk mengurangi ketergantungan terhadap bahan bakar minyak pemerintah telah menerbitkan Peraturan Presiden Republik Indonesia nomor 5 tahun 2006 tentang Kebijakan Energi Nasional untuk mengembangkan sumber energi alternatif sebagai pengganti bahan bakar minyak[1]. Kebijakan tersebut menekankan pada sumber daya yang dapat diperbaharui sebagai altenatif pengganti bahan bakar minyak.

Biogas merupakan energi terbarukan yang dapat digunakan sebagai energi alternatif untuk mengganti bahan bakar yang berasal dari fosil seperti minyak tanah dan gas alam. Biogas yang juga merupakan salah satu jenis bioenergi dihasilkan dari bahan-bahan organik seperti kotoran ternak, limbah kotoran manusia, jerami, sekam dan daun-daun yang mengalami proses fermentasi atau proses metanisasi[2].
Kota Pontianak merupakan Ibukota Provinsi Kalimantan Barat memiliki luas daerah sebesar 107,82 $\mathrm{Km}^{2}$ dengan jumlah penduduk saat ini sekitar 618.388 jiwa dengan laju pertumbuhan penduduk sebesar $1,8 \%$ per tahun[3]. Dengan jumlah penduduk yang cukup besar tentunya akan menghasilkan limbah kotoran manusia yang cukup besar juga yang saat ini belum dimanfaatkan.

Pemanfaatan limbah kotoran manusia sebagai sumber energi dapat menghasilkan gas metana melalui proses fermentasi, dimana gas metana yang dihasilkan tersebut dapat dikonversikan menjadi energi listrik, sehingga limbah kotoran manusia tersebut yang tadinya merupakan suatu bahan yang tidak berharga dapat dijadikan sebagai bahan bakar yang ramah lingkungan dan tentu saja penggunaannya akan mengurangi ketergantungan akan pemakaian minyak bumi.

\section{Tinjauan Pustaka}

2.1. Pengertian Biogas

Biogas merupakan sebuah proses produksi gas bio dari material organik dengan bantuan bakteri. Proses degradasi material organik ini tanpa melibatkan oksigen disebut pencernaan anaerob atau anaerobic digestion (AD). Gas yang dihasilkan sebagian besar (lebih 50\%) berupa gas methana. Tabel 1 menunjukkan perbandingan komposisi antara biogas, gas alam, dan gas pada Tempat Pembuangan Akhir (TPA) sampah (Landfill Gas)

Tabel 1. Komposisi Biogas, Gas Alam, dan Landfill Gas[4]

\begin{tabular}{|c|c|c|c|c|}
\hline Komposisi & Unit & Biogas & $\begin{array}{c}\text { Gas } \\
\text { Alam }\end{array}$ & $\begin{array}{c}\text { Landfill } \\
\text { Gas }\end{array}$ \\
\hline Methana $\mathrm{CH}_{4}$ & $\%$ Vol. & $55-70$ & 91 & $45-58$ \\
\hline Ethana $\mathrm{C}_{2} \mathrm{H}_{6}$ & $\%$ Vol. & 0 & 5,1 & 0 \\
\hline Propana $\mathrm{C}_{3} \mathrm{H}_{8}$ & $\%$ Vol. & 0 & 1,8 & 0 \\
\hline Butana $\mathrm{C}_{4} \mathrm{H}_{10}$ & $\%$ Vol. & 0 & 0,9 & 0 \\
\hline Pentana & $\%$ Vol. & 0 & 0,3 & 0 \\
\hline $\mathrm{CO}_{2}$ & $\%$ Vol. & $30-45$ & 0,61 & $32-45$ \\
\hline Nitrogen $\mathrm{N}_{2}$ & $\%$ Vol. & $0-2$ & 0,32 & $0-3$ \\
\hline $\begin{array}{l}\text { Volatile Organic } \\
\text { Compounds (VOC) }\end{array}$ & $\%$ Vol. & 0 & 0 & $0,25-0,5$ \\
\hline Hidrogen $\mathrm{H}_{2}$ & $\%$ Vol. & 0 & 0 & $\begin{array}{c}\text { Terdeteks } \\
\mathrm{i}<1 \%\end{array}$ \\
\hline $\begin{array}{l}\text { Hidrogen Sulfida } \\
\mathrm{H}_{2} \mathrm{~S}\end{array}$ & ppm & $<500$ & $<1$ & $10-200$ \\
\hline Amonia $\mathrm{NH}_{3}$ & ppm & $<100$ & 0 & 0 \\
\hline $\begin{array}{l}\text { Karbon Monoksida } \\
\text { CO }\end{array}$ & ppm & 0 & 0 & terdeteksi \\
\hline
\end{tabular}

Material organik yang terkumpul pada digester (reaktor) akan diuraikan menjadi dua tahap dengan bantuan dua jenis bakteri. Tahap pertama material 
organik akan didegradasi menjadi asam-asam lemah dengan bantuan bakteri pembentuk asam. Bakteri ini akan menguraikan sampah pada tingkat hidrolisis dan asidifikasi. Hidrolisis yaitu penguraian senyawa kompleks atau senyawa rantai panjang seperti lemak, protein, karbohidrat menjadi senyawa yang sederhana. Sedangkan asidifikasi yaitu pembentukan asam dari senyawa sederhana[2].

\subsection{Proses Biokimia pada Pencernaan Anaerob}

Seperti yang dinyatakan sebelumnya, AD adalah proses mikrobiologis dekomposisi bahan organik tanpa adanya oksigen. Produk utama dari proses ini adalah biogas dan digestate.

Proses pembentukan biogas adalah hasil dari langkah-langkah proses terkait, di mana pada tahap awal bahan terus dipecah menjadi unit yang lebih kecil. Kelompok tertentu dari mikroorganisme terlibat dalam setiap langkah individu. Organisme ini berturut-turut menguraikan produk dari langkah-langkah sebelumnya. Diagram menyederhanakan proses $\mathrm{AD}$, yang ditunjukkan pada Gambar 1, menyoroti empat langkah utama proses yaitu: hidrolisis, asidogenesis, asetogenesis, dan methanogenesis.

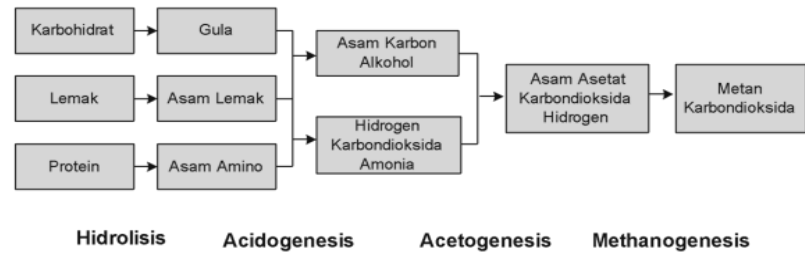

Gambar 1. Langkah utama pada Anaerobic Digestion[2]

Langkah-langkah proses dalam Gambar 1 berjalan sejajar dalam ruang dan waktu, dalam tangki digester. Kecepatan proses dekomposisi total ditentukan oleh kecepatan reaksi dari rantai. Selama hidrolisis, relatif sejumlah kecil biogas yang dihasilkan. Produksi biogas mencapai puncaknya selama methanogenesis.

a. Hidrolisis

Hidrolisis adalah proses dimana bahan organik kompleks (polimer) diurai menjadi unit yang lebih kecil (mono dan oligomer). Selama hidrolisis, polimer seperti karbohidrat, lipid, asam nukleat dan protein diubah menjadi glukosa, gliserol, purin dan piridina. Mikroorganisme hidrolitik mengeluarkan enzim hidrolitik, mengkonversi biopolimer menjadi senyawa sederhana dan larut.

Produk yang dihasilkan dari hidrolisis selanjutnya diurai oleh mikroorganisme terlibat dan digunakan untuk proses metabolisme mereka sendiri

b. Acidogenesis/Pengasaman

Selama asidogenesis, produk hidrolisis dikonversi oleh Acidogenic (fermentatif) bakteri ke dalam substrat metanogen. Gula sederhana, asam amino, dan asam lemak yang terdegradasi menjadi asetat, karbon dioksida dan hidrogen $(70 \%)$ dalam bentuk asam lemak volatil (VFA) dan alkohol (30\%).

\section{c. Acetogenesis}

Produk dari asidogenesis, yang tidak dapat langsung diubah menjadi metana oleh bakteri metanogen, diubah menjadi substrat metanogen selama asetogenesis. VTA dan alkohol dioksidasi menjadi substrat metanogen seperti asetat, hidrogen dan karbondioksida. VFA, dengan rantai karbon lebih dari dua unit dan alkohol, dengan rantai karbon lebih dari satu unit, dioksidasi menjadi asetat dan hidrogen. Selama metanogenesis, hidrogen diubah menjadi metana. Asetogenesis dan metanogenesis biasanya berjalan paralel, sebagai simbiosis dari dua kelompok organisme.

d. Methanogenesis

Produksi metana dan karbon dioksida dari produk antara (intermediate product) dilakukan oleh bakteri metanogen. $70 \%$ dari metana yang terbentuk berasal dari asetat, sedangkan sisanya $30 \%$ dihasilkan dari konversi hidrogen $(\mathrm{H})$ dan karbon dioksida $\left(\mathrm{CO}_{2}\right)$. Methanogenesis merupakan langkah penting dalam seluruh proses $\mathrm{AD}$, karena merupakan yang paling lambat dari proses reaksi biokimia. Methanogenesis ini sangat dipengaruhi oleh kondisi operasi. Komposisi bahan baku, tingkat makan, suhu, dan $\mathrm{pH}$ adalah contoh faktor yang mempengaruhi proses metanogenesis. Digester yang overloading, perubahan suhu atau masuknya oksigen dapat mengakibatkan penghentian produksi metana.

\subsection{Tangki Pencernaan}

Digester merupakan tempat reaksi fermentasi anaerob limbah organik menjadi biogas terjadi. Berdasarkan bentuk tangki digester, secara umum dikenal 3 (tiga) tipe utama reaktor biogas yakni tipe balon (balloon type), tipe kubah tetap (fixed-dome type) dan tipe kubah penutup mengambang (floating drum type)[5].

a. Tipe Balon[5]

Reaktor balon merupakan jenis reaktor yang banyak digunakan pada skala rumah tangga yang menggunakan bahan plastik sehingga lebih efisien dalam penanganan dan perubahan tempat biogas. Reaktor ini terdiri dari satu bagian yang berfungsi sebagai digester dan penyimpan gas masing masing bercampur dalam satu ruangan tanpa sekat.

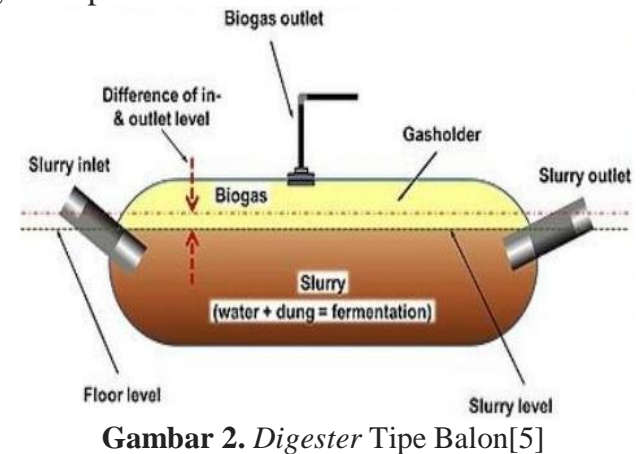

Material organik terletak dibagian bawah karena memiliki berat yang lebih besar dibandingkan gas yang akan mengisi pada rongga atas.

b. Tipe Kubah Tetap[5]

Digester jenis ini mempunyai volume tetap. Seiring dengan dihasilkannya biogas, terjadi peningkatan tekanan dalam digester. Karena itu, dalam konstruksinya digester jenis kubah tetap, gas yang terbentuk akan 
segera dialirkan ke pengumpul gas di luar reaktor. Indikator produksi gas dapat dilakukan dengan memasang indikator tekanan.

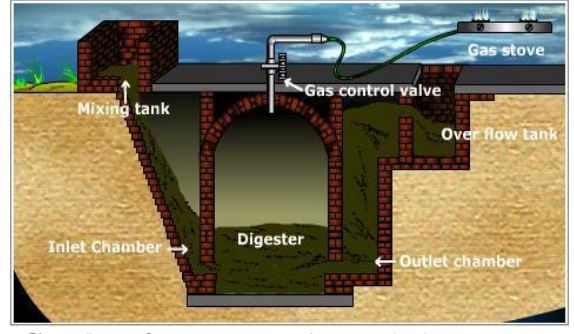

Gambar 3. Digester Tipe Kubah Tetap[5]

c. Tipe Kubah Mengambang[5]

Pada digester tipe ini terdapat bagian yang reaktor yang dapat bergerak seiring dengan kenaikan tekanan reaktor. Pergerakan bagian kubah dapat dijadikan indikasi bahwa produksi biogas sudah mulai atau sudah terjadi. Bagian yang bergerak juga berfungsi sebagai pengumpul biogas. Kelemahannya adalah membutuhkan teknik khusus untuk membuat tampungan gas bergerak seiring naik atau turunnya produksi biogas. Kelemahan lainnya adalah material dari tampungan gas yang dapat bergerak harus dipilih yang mempunyai sifat tahan korosi, hal tersebut menyebabkan harganya relatif lebih mahal.

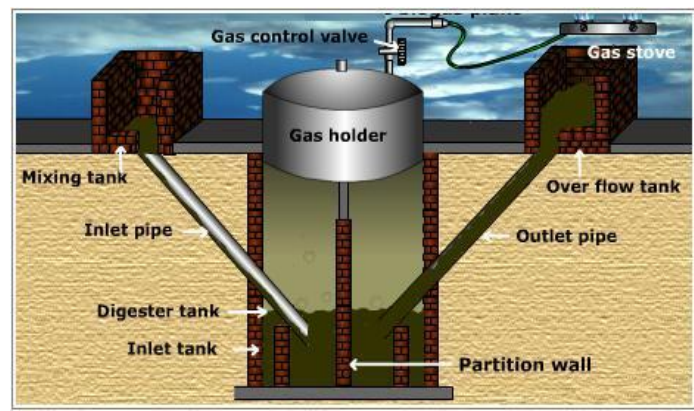

Gambar 4. Digester Tipe Kubah Mengambang[5]

\subsection{Ukuran Digester Biogas}

Ukuran tangki digester biogas tergantung dari jumlah, kualitas dan jenis limbah organik yang tersedia dan temperatur saat proses fermentasi anaerob. Di bawah ini gambar bentuk penampang silender digester anaerob (Cylindrical Shaped Bio-Gas Digester Body) dengan penjelasan sebagai berikut:

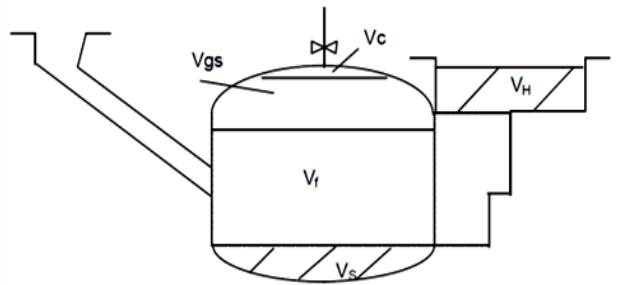

Gambar 5. Penampang Digester Biogas Silinder[6] Keterangan:

$\mathrm{V}_{\mathrm{c}}=$ Volume Ruangan penampungan gas (gas collecting chamber)

$\mathrm{V}_{\mathrm{gs}}=$ Volume Ruangan Penyimpanan Gas (gas storage chamber)
$\mathrm{V}_{\mathrm{f}}=$ Volume Ruangan Fermentasi (fermentation chamber)

$\mathrm{V}_{\mathrm{H}}=$ Volume Ruangan Hidrolik (hydraulic chamber)

$\mathrm{V}_{\mathrm{S}}=$ Volume lapisan penampungan lumpur (sludge layer)

Total Volume Digester adalah[6] :

$$
\mathrm{V}=\mathrm{V}_{\mathrm{c}}+\mathrm{V}_{\mathrm{gs}}+\mathrm{V}_{\mathrm{f}}+\mathrm{V}_{\mathrm{S}}
$$

Untuk mendisain tangki digester biogas, dapat dilihat pada gambar dimensi geometrikal tangki digester di bawah ini:

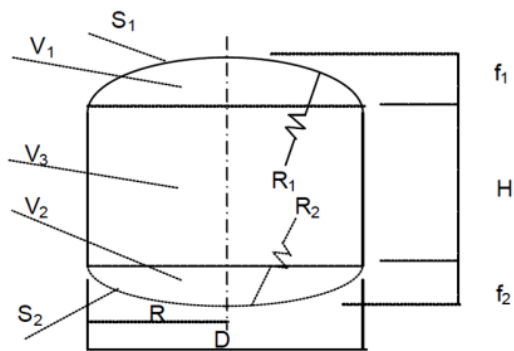

Gambar 6. Dimensi geometri penampang Digester Biogas[6]

Dari Gambar 6 berlaku bentuk geometri ruangan digester biogas dengan ketentuan sebagai berikut:

Tabel 2. Dimensi Geometrikal Ukuran Tangki Digester

\begin{tabular}{ll}
\multicolumn{1}{c}{ Silinder[4] } \\
\hline \multicolumn{1}{c}{ VOLUME } & \multicolumn{1}{c}{ DIMENSI GEOMETRI } \\
\hline $\mathrm{V}_{\mathrm{c}} \leq 5 \% \mathrm{~V}$ & $\mathrm{D}=1.3078 \cdot \mathrm{V}^{1 / 3}$ \\
$\mathrm{~V}_{\mathrm{s}} \leq 15 \% \mathrm{~V}$ & $\mathrm{~V}_{1}=0.0827 \mathrm{D}^{3}$ \\
$\mathrm{~V}_{\mathrm{gs}}+\mathrm{V}_{\mathrm{f}}=80 \% \mathrm{~V}$ & $\mathrm{~V}_{2}=0.05011 \mathrm{D}^{3}$ \\
$\mathrm{~V}_{\mathrm{gs}}=\mathrm{V}_{\mathrm{H}}$ & $\mathrm{V}_{3}=0.3142 \mathrm{D}^{3}$ \\
$\mathrm{~V}_{\mathrm{gs}}=0.5\left(\mathrm{~V}_{\mathrm{gs}}+\mathrm{V}_{\mathrm{f}}+\mathrm{V}_{\mathrm{s}}\right)$ & $\mathrm{R}_{1}=0.725 \mathrm{D}$ \\
$\mathrm{K}$, & $\mathrm{R}_{2}=1.0625 \mathrm{D}$ \\
dimana K adalah Tingkat & $\mathrm{f}_{1}=\mathrm{D} / 5$ \\
Produksi Gas per $\mathrm{m}^{3}$ & $\mathrm{f}_{2}=\mathrm{D} / 8$ \\
volume digester per hari & $\mathrm{S}_{1}=0.911 \mathrm{D}^{2}$ \\
& $\mathrm{~S}_{2}=0.8345 \mathrm{D}^{2}$ \\
\hline
\end{tabular}

2.5. Pemanfaatan Limbah Kotoran Manusia sebagai Biogas

Mengingat kemudahan proses dan tidak ada starter (bibit mikroorganisme) yang dibutuhkan dalam prosesnya, limbah kotoran manusia memiliki potensi yang sama dalam pembangkitan biogas dengan kotoran sapi. Keuntungan ini karena kotoran manusia dan kotoran ternak berasal dari degradasi anaerob di saluran gastrointestinal, sehingga memungkinkan untuk mengandung bakteri faecal anaerob yang tinggi. Komponen ekskreta manusia dapat dilihat pada Tabel 3.

Berdasarkan data pada Tabel 4 , ada kemungkinan potensi biogas per $\mathrm{kg}$ kotoran manusia menjadi sama atau lebih tinggi dari pupuk kandang, dan kadar metana dalam biogas bisa mencapai 70\%. Fakta lain yang membuat kotoran manusia merupakan bahan baku yang menguntungkan adalah pH-nya sekitar 7,3, kisaran $\mathrm{pH}$ optimum untuk produksi biogas. 
Tabel 3. Komponen Kotoran Manusia[7]

\begin{tabular}{lcc}
\hline Komponen & Unit & Jumlah \\
\hline Massa Kering & $\mathrm{g} / \mathrm{kg}$ & 216 \\
Total Nitrogen & $\mathrm{g} / \mathrm{kg}$ & 11 \\
Total Phosphorus & $\mathrm{g} / \mathrm{kg}$ & 4 \\
Potassium & $\mathrm{g} / \mathrm{kg}$ & 8 \\
Kelembaban & $\%$ & 78 \\
Kandungan Bahan Kering & $\%$ & 22 \\
pH & - & $7-9$ \\
\hline
\end{tabular}

Tabel 4. Perbandingan Bahan Baku dan Gas yang Dihasilkan[7]

\begin{tabular}{lcccc}
\hline Sumber & $\begin{array}{c}\text { Jumlah } \\
\text { Kotoran/hari/kg }\end{array}$ & $\begin{array}{c}\% \\
\text { Air }\end{array}$ & $\begin{array}{c}\text { \% Dry } \\
\text { Matter }\end{array}$ & $\begin{array}{c}\text { Biogas }^{3} / \mathbf{k g} \\
\text { kotoran kering }\end{array}$ \\
\hline Sapi & $20-30$ & 80 & 20 & $0,023-0,040$ \\
Sapi & $20-30$ & 80 & 20 & $0,023-0,040$ \\
Perah & & & & \\
Kerbau & $30-40$ & 83 & 20 & $0,023-0,040$ \\
Ayam & $0,15-0,20$ & 72 & 28 & $0,065-0,116$ \\
Babi & $3,00-4,00$ & 67 & 33 & $0,04-0,059$ \\
Manusia & $0,10-0,40$ & 77 & 23 & $0,02-0,028$ \\
\hline
\end{tabular}

Proses pembangkitan biogas dengan menggunakan limbah kotoran manusia pada dasarnya sama dengan sistem biogas pupuk kandang. Limbah kotoran manusia dimasukkan ke dalam digester setiap hari, sementara gas dan lumpur yang dihasilkan juga secara bersamaan akan keluar dari digester dengan jumlah tertentu berdasarkan waktu retensi hidrolik (HRT) pada digester. Lumpur tersebut bisa diproses lebih lanjut menjadi pupuk.

Kelemahan utama kotoran manusia adalah rendahnya rasio $\mathrm{C} / \mathrm{N}$ yang kira-kira 6-10. Ini lebih rendah dari rasio $\mathrm{C} / \mathrm{N}$ yang diharapkan pada produksi biogas sebesar 25-30. Ini berarti bahwa jumlah nitrogen lebih besar dari pada jumlah karbon, yang mengakibatkan banyak pembentukan amonia dari proses dekomposisi dan selanjutnya meningkatkan $\mathrm{pH}$ sistem menjadi basa. Untuk mengatasi kekurangan ini, penambahan bahan baku $\mathrm{C} / \mathrm{N}$ ratio tinggi sangat dibutuhkan seperti jerami padi (rasio $\mathrm{C} / \mathrm{N}$ 12,5-25), sekam padi (rasio C/N 100-125), atau tongkol jagung (rasio C/N 50)[7].

\subsection{Konversi Energi Listrik dari Gas Metan}

Untuk menghitung potensi energi listrik yang dihasilkan, maka potensi gas metan dalam $\mathrm{m}^{3}$ harus disetarakan dalam satuan energi listrik ( $\mathrm{kWh}$ ) sehingga 1 $\mathrm{m}^{3}$ gas metan menghasilkan energi listrik sebesar 11,17 kWh, sebagaimana Tabel 5.

Tabel 5. Konversi Energi Gas Metan menjadi Energi Listrik[8]

\begin{tabular}{ll}
\hline \multicolumn{1}{c}{ Jenis Energi } & \multicolumn{1}{c}{ Setara Energi } \\
\hline $1 \mathrm{~kg}$ Gas Metan & $6,13 \times 10^{7} \mathrm{~J}$ \\
$1 \mathrm{kWh}$ & $3,6 \times 10^{6} \mathrm{~J}$ \\
$1 \mathrm{~m}^{3}$ gas metan (Massa Jenis & $4,0213 \times 10^{7} \mathrm{~J}$ \\
Gas Metan $=0,656 \mathrm{~kg} / \mathrm{m}^{3}$ ) & $11,17 \mathrm{kWh}$ \\
$1 \mathrm{~m}^{3}$ gas metan & \\
\hline
\end{tabular}

\section{Hasil Penelitian dan Pembahasan}

3.1. Analisis Potensi Energi Listrik dari Limbah Kotoran Manusia di Kota Pontianak

a. Jumlah berat limbah kotoran manusia

Jumlah penduduk Kota Pontianak tahun 2016 berjumlah 618.388 jiwa[3]. Apabila jumlah kotoran manusia (tinja) perhari adalah $0,250 \mathrm{~kg} /$ orang/hari[7] maka akan dihasilkan berat limbah kotoran:

$0,250 \mathrm{~kg} / \mathrm{orang} / \mathrm{hari} \times 618.388$ jiwa $=154.597 \mathrm{~kg} / \mathrm{hari} \approx$ 154,6 ton/hari

b. Nilai Total Solid

Berdasarkan Tabel 4, kotoran manusia terdiri dari $77 \%$ air dan $23 \%$ materi padat (Total Solid), sehingga nilai total solid :

$23 \% \times 154.597 \mathrm{~kg} / \mathrm{hari}=35.557,31 \mathrm{~kg} / \mathrm{hari} \approx 35,56$

ton/hari

c. Jumlah Volume Biogas yang Dihasilkan

Berdasarkan Tabel 4 volume biogas yang dihasilkan dari limbah kotoran manusia adalah :

Volume biogas $=0,02 \mathrm{~m}^{3} / \mathrm{kg} \times 154.597 \mathrm{~kg} /$ hari $=$ $3.091,94 \mathrm{~m}^{3}$ /hari

d. Jumlah Volume Gas Metan yang Dihasilkan

Dengan mengetahui volume biogas yang dihasilkan sebesar 3.091,94 m³ /hari maka volume gas metan $\left(\mathrm{CH}_{4}\right)$ dapat diketahui melalui Tabel 1 yaitu:

Volume Gas Metan $=70 \% \times$ Volume Biogas

$$
\begin{array}{r}
=70 \% \times 3.091,94 \mathrm{~m}^{3} / \text { hari } \\
=2.164,36 \mathrm{~m}^{3} / \text { hari }
\end{array}
$$

e. Nilai Energi dan Daya Listrik yang dihasilkan

Dengan mengetahui volume gas metan yang dihasilkan, yaitu 2.164,36 $\mathrm{m}^{3} /$ hari, maka berdasarkan Tabel 5 akan didapatkan energi listrik:

Energi Listrik $=2.164,36 \mathrm{~m}^{3} /$ hari $\times 11,17 \mathrm{kWh}$

$$
=24.157,88 \mathrm{kWh} / \mathrm{hari}
$$

Daya Listrik $=\frac{24.157,88 \mathrm{kWh} / \mathrm{hari}}{24 \mathrm{jam}}$

$$
=1.007,33 \mathrm{~kW}
$$

$$
\approx 1 \mathrm{MW} \text {. }
$$

f. Menentukan Volume Digester

Agar proses fermentasi anaerob dapat berjalan dengan optimum maka nilai $\mathrm{C} / \mathrm{N}$ dari bahan baku berkisar antara 25-30. Nilai C/N kotoran manusia adalah $8[10]$, sehingga harus ditambahkan material organik lain sehingga nilai $\mathrm{C} / \mathrm{N}$ menjadi minimum 25 , antara lain digunakan jerami dengan nilai $\mathrm{C} / \mathrm{N}$ adalah 70 . Dengan menggunakan persamaan matematika maka jumlah massa jerami $\left(\mathrm{M}_{2}\right)$ yang harus ditambahkan sebanyak:

$$
\begin{array}{r}
\mathrm{C} / \mathrm{N}_{\text {total }}=\frac{\left(\mathrm{M}_{1} \times \mathrm{C} / \mathrm{N}_{1}\right)+\left(\mathrm{M}_{2} \times \mathrm{C} / \mathrm{N}_{2}\right)}{\left(\mathrm{M}_{1}+\mathrm{M}_{2}\right)} \\
25=\frac{(35,56 \text { ton } \times 8)+\left(\mathrm{M}_{2} \times 70\right)}{\left(35,56 \text { ton }+\mathrm{M}_{2}\right)}
\end{array}
$$

$\left(2884,48\right.$ ton $\left.+70 \mathrm{M}_{2}\right)=\left(889\right.$ ton $\left.+25 \mathrm{M}_{2}\right)$

$$
\begin{aligned}
45 \mathrm{M}_{2} & =604,52 \text { ton } \\
\mathrm{M}_{2} & =\frac{604,52 \text { ton }}{45} \\
& =13,43 \text { ton }
\end{aligned}
$$

Sehingga $M_{\text {jerami }}=13,43$ ton, dengan berat kotoran manusia dan jerami adalah 150 ton $+13,43$ ton $=163,43$ ton. Selanjutnya dialirkan air dengan perbandingan 1:1[9] sehingga didapatkan berat campuran bahan organik (kotoran+ jerami+air) atau slurry sebanyak = 326,82 ton atau dengan volume $=326,82 \mathrm{~m}^{3} /$ hari. 
Untuk menghitung volume digester yang perlu diperhatikan adalah tipe digester, volume slurry harian, waktu retensi/digestifikasi, dan volume biogas.

Pada penelitian ini tipe digester yang akan digunakan adalah tipe fixed dome. Waktu digestifikasi/retensi tergantung pada temperatur lingkungan dan temperatur digester. Dengan kondisi tropis seperti di Indonesia, pada suhu $25-35^{\circ} \mathrm{C}$, waktu digestifikasi kira-kira $30-40$ hari[5]. Semakin pendek waktu digestifikasi maka akan mengurangi volume digester dan sebaliknya waktu digestifikasi yang panjang akan menambah volume digester.

Dengan menentukan waktu digestifikasi 30 hari maka dengan Persamaan 3 volume digester untuk ruang digestifikasi $\left(\mathrm{V}_{\mathrm{f}}\right)$ dapat diketahui:

$\mathrm{V}_{\mathrm{f}}\left(\mathrm{m}^{3}\right)=$ waktu digestifikasi $\times$ bahan organik harian $\left(\mathrm{m}^{3} / \mathrm{hari}\right)$

$=30$ hari $\times 326,82 \mathrm{~m}^{3} /$ hari

$=9.804,6 \mathrm{~m}^{3}$

Volume Digester total (V) harus dapat menampung jumlah dari $\mathrm{V}_{\mathrm{f}}$ dan volume ruang penyimpanan gas $\left(\mathrm{V}_{\mathrm{gs}}\right)$. Ukuran $\mathrm{V}_{\mathrm{gs}}$ sama dengan 1,7 kali jumlah biogas harian yang dihasilkan[11] sehingga nilai $\mathrm{V}_{\mathrm{gs}}$ :

$$
\begin{aligned}
\mathrm{V}_{\mathrm{gs}}\left(\mathrm{m}^{3}\right) \quad=1,7 \times \text { Volume biogas } \\
=1,7 \times 3.091,94 \mathrm{~m}^{3} / \text { hari } \\
=5.256,3 \mathrm{~m}^{3}
\end{aligned}
$$

Sehingga volume digester total (V) adalah:

$80 \% \mathrm{~V}\left(\mathrm{~m}^{3}\right)=\mathrm{V}_{\mathrm{f}}+\mathrm{V}_{\mathrm{gs}}$

$$
\begin{aligned}
\mathrm{V}\left(\mathrm{m}^{3}\right) & =\frac{9.804,6 \mathrm{~m}^{3}+5 \cdot 256,3 \mathrm{~m}^{3}}{0,8} \\
& =\frac{15.060,9 \mathrm{~m}^{3}}{0,8} \\
= & 18.826,13 \mathrm{~m}^{3}
\end{aligned}
$$

\subsection{Perhitungan Energi Listrik PLT Biogas}

Konversi energi listrik dari biogas dilakukan dengan mengubah energi potensial yang ada dalam biogas menjadi energi mekanik, kemudian diubah menjadi listrik. saat ini teknologi konversi energi listrik dari biogas yang tersedia di pasaran yaitu gas engine dan microturbines.

Efisiensi sangat penting sebagai aspek yang harus dipertimbangkan dalam pemilihan teknologi konversi, efisiensi berhubungan langsung dengan jumlah energi yang dihasilkan, semakin tinggi efisiensi semakin besar pula energi output yang dihasilkan, demikian pula sebaliknya. Untuk efisiensi dari microturbine sebesar $30 \%$, dengan capacity factor $0,8[2]$.

Untuk menghitung energi listrik yang dihasilkan digunakan Persamaan 4[12]:

$$
\begin{aligned}
& \mathrm{E}_{\mathrm{L}}=\mathrm{V}_{\mathrm{BS}} \times \% \mathrm{CH}_{4} \times \mathrm{H}_{\text {metan }} \times \mathrm{CF} \times \eta_{\mathrm{el}} \\
& \text { dimana: } \quad \mathrm{V}_{\mathrm{BS}}=\text { Volume Biogas }\left(\mathrm{m}^{3}\right) \\
& \% \mathrm{CH}_{4}=\text { Persentase gas metan } \\
& \mathrm{H}_{\text {metan }}=\text { Nilai Kalor Metan }\left(\mathrm{kWh} / \mathrm{m}^{3}\right) \\
& \mathrm{CF}=\text { Capacity Factor } 0,8 \\
& \eta_{\mathrm{el}}=\text { Efisiensi microturbine } \\
& \text { Karena: } \\
& \mathrm{V}_{\mathrm{BS}} \times \% \mathrm{CH}_{4} \times \mathrm{H}_{\text {metan }}=\text { Potensi Energi Listrik }(\mathrm{E}),
\end{aligned}
$$

maka:

$$
\mathrm{E}_{\mathrm{L}}=\mathrm{E} \times \mathrm{CF} \times \eta_{\mathrm{el}}
$$

Diketahui bahwa energi listrik yang dihasilkan sebesar $23.457 \mathrm{kWh} /$ hari, sehingga nilai $\mathrm{E}_{\mathrm{L}}$ adalah:

$$
\begin{aligned}
\mathrm{E}_{\mathrm{L}} & =\mathrm{E} \times \mathrm{CF} \times \eta_{\mathrm{el}} \\
& =24.157,88 \mathrm{kWh} / \text { hari } \times 0,8 \times 30 \% \\
& =5.797,9 \mathrm{kWh} / \text { hari }
\end{aligned}
$$

Sehingga daya yang dibangkitkan adalah :

$$
\begin{array}{r}
\mathrm{P}_{\mathrm{L}}=\frac{5.797,9 \mathrm{kWh} / \text { hari }}{24} \\
=241,6 \mathrm{~kW}
\end{array}
$$

\subsection{Komponen Biaya dan Pendapatan PLT Biogas}

Komponen biaya terdiri dari biaya investasi (investment cost) dan biaya operasional dan perawatan (Operational and Maintenance - O\&M Cost). Biaya modal berupa Biogas Plant, Pengolahan limbah dan sludge, dan biaya investasi pembangkit (Microturbine Generator) $250 \mathrm{~kW}$. Sedangkan biaya operasional dan

\begin{tabular}{|c|c|c|}
\hline Komponen O\&M & Biaya & Unit \\
\hline Perawatan Biogas & 2 & $\%$ (Biaya \\
\hline Plant & & Investasi) \\
\hline Microturbine $250 \mathrm{~kW}$ & 0,012 & USD/kW \\
\hline Operator (4 orang) & 10.000 & USD/tahun \\
\hline Administrasi (2 orang) & 5.000 & USD/tahun \\
\hline Unit fuel cost & 0,506 & USD/ton \\
\hline
\end{tabular}
pemeliharaan berupa O\&M Biogas Plant, biaya O\&M Microturbine Generator $250 \mathrm{~kW}$ serta biaya karyawan/ operator. Sedangkan untuk komponen pendapatan terdiri dari penjualan listrik dan penjualan sludge/kompos sebagai pupuk organik.

3.3.1. Perhitungan Biaya Investasi dan Biaya O\&M

Biaya ini digunakan untuk investasi termasuk reaktor, tangki penyimpanan, pipa sambungan untuk difusi, pencampuran dan distribusi dari biogas, turbin untuk produksi energi, serta serta biaya pengolahan limbah dan sludge, termasuk untuk kompos. Komponen biaya dimaksud ditunjukkan pada Tabel 6:

Tabel 6 Biaya Investasi (dalam USD)[13]

\begin{tabular}{lcc}
\hline \multicolumn{1}{c}{ Komponen Investasi } & Biaya & Unit \\
\hline Biogas Plant & 5.000 & $\mathrm{USD}_{\mathrm{kW}}$ \\
Microturbine $250 \mathrm{~kW}$ & 1.100 & $\mathrm{USD}_{\mathrm{el}}$ \\
Pengolahan limbah \& & 110 & $\mathrm{USD} / \mathrm{ton}$ \\
Sludge & & \\
\hline
\end{tabular}

Biaya O\&M terdiri dari biaya perawatan Biogas Plant, Microturbine, biaya pegawai (operator dan administrasi), dan unit fuel cost. Komponen biaya O\&M ditunjukkan pada Tabel 7.

Tabel 7 Biaya Operasional dan Perawatan (dalam USD)[13]

Dalam perhitungan ini digunakan 1 (satu) buah tabung reaktor/digester dengan ukuran 18.826,13 $\mathrm{m}^{3}$ dengan jenis fixed dome. Berdasarkan Persamaan 4 dan 5 , didapatkan hasil perhitungan daya listrik dengan menggunakan microturbine sebesar 241,6 kW sehingga menggunakan Microturbine $250 \mathrm{~kW}$. 


\subsubsection{Perhitungan Komponen Pendapatan}

Untuk perhitungan komponen pendapatan (income) terdiri dari dua komponen yaitu biaya penjualan listrik dan penjualan sludge/kompos sebagai pupuk organik.

\section{a) Penjualan Listrik}

Biaya penjualan listrik dapat dihitung dengan jumlah energi listrik per tahun dikali harga energi listrik per $1 \mathrm{kWh}$. Dalam waktu satu tahun tidak selamanya suatu sistem pembangkit listrik tenaga biogas dapat beroperasi secara penuh, perlu juga diperhatikan faktor pemeliharaan untuk masing-masing komponen sistem. Dengan menggunakan asumsi 10 hari waktu pemeliharaan per tahun, maka perhitungan energi listrik yang dapat dibangkitkan dalam waktu 1 (satu) tahun adalah :

$\mathrm{E}_{\mathrm{L}}=5.797,9 \mathrm{kWh} /$ hari $\times 355$ hari

$=2.058 .254,5 \mathrm{~kW} \approx 2.058,3 \mathrm{MW}$

Berdasarkan Peraturan Menteri ESDM Nomor 27 Tahun 2014 tentang Pembelian Tenaga Listrik dari Pembangkit Listrik Tenaga Biomassa dan Pembangkit Listrik Tenaga Biogas oleh PT.Perusahaan Listrik Negara (Persero) untuk biogas adalah sebesar Rp. 1.050,00 /kWh x F jika terinterkoneksi pada tegangan menengah oleh PT. PLN (Persero) dengan besaran untuk wilayah Kalimantan, $\mathrm{F}=1,30$ [14] maka pendapatan per tahun dari penjualan listrik yang berasal dari biogas adalah:

Penjualan Listrik

$=5.797,9 \mathrm{kWh} / \mathrm{hari} \times 355$ hari $\times \mathrm{Rp} 1.050,00 / \mathrm{kWh}$

$\times 1,30$

$=\operatorname{Rp} 2.809 .517 .393 \approx 2,8$ Milyar/tahun.

b) Penjualan Sludge/Kompos sebagai Pupuk Organik

Sludge adalah limbah keluaran berupa lumpur dari lubang pengeluaran digester setelah mengalami proses fermentasi anaerobic. Setelah ekstrasi biogas (energi), sludge dari digester merupakan produk samping dari sistem pencernaan digester. Sludge mengandung senyawa yang dapat membantu menyuburkan tanah dan meningkatkan produksi tanaman.

Massa yang hilang saat pengomposan bahan segar kira-kira sampai 3/4 dari volume awal. Ini berarti bahwa dari $100 \%$ bahan yang dikomposkan kira-kira sekitar $25 \%$ hasil limbah yang masuk dalam kompos dan $75 \%$ lainnya meninggalkan sistem sebagai air yang diuapkan dan padatan volatile yang terdegradasi[14].

Jumlah limbah kotoran manusia yang dihasilkan perhari sebesar $154.597 \mathrm{~kg} /$ hari, sehingga jumlah sludge yang dihasilkan adalah $25 \% \times 154.597 \mathrm{~kg} / \mathrm{hari}=$ $38.649,25 \mathrm{~kg} /$ hari atau $14.106 .976,2 \mathrm{~kg} /$ tahun $\approx 14.107$ ton/tahun. Dengan harga pupuk organik sebesar Rp 500/kg[15] maka:

Penjualan sludge

$$
\begin{aligned}
& =14.106 .976,2 \mathrm{~kg} / \text { tahun } \times \operatorname{Rp} 500 \\
& =\operatorname{Rp} 7.053 .488 .100
\end{aligned}
$$

Tabel 8 Perhitungan Komponen Pendapatan (income)

\begin{tabular}{lc}
\hline \multicolumn{1}{c}{ Komponen } & Jumlah (Rp) \\
\hline Penjualan Listrik & 2.809 .517 .393 \\
Penjualan Sludge/Kompos & 7.053 .488 .100 \\
\hline \multicolumn{1}{c}{ Total } & $\mathbf{9 . 8 6 3 . 0 0 5 . 4 9 3}$ \\
\hline 3
\end{tabular}

3.4 Analisis Ekonomi PLT Biogas

Analisis ekonomi kelayakan pemanfaatan limbah kotoran manusia sebagai bahan baku biogas untuk pembangkit listrik dilakukan dengan menggunakan Teknik Analisis Anggaran Modal (Budgeting Capital) yang terdiri dari Payback Period (PBD), Net Present Value (NPV) dan Internal Rate of Return (IRR). Analisis ekonomi ini digunakan untuk mengetahui karakteristik finansial pemanfaatan PLT Biogas berdasarkan total aliran pendapatan tahunan (inflow) dan total aliran biaya tahunan (outflow) untuk jenis teknologi konversi pembangkit yang digunakan yaitu microturbine $250 \mathrm{~kW}$.

Berdasarkan Tabel 6 dan 7, dengan asumsi bahwa $1 \mathrm{USD}=\operatorname{Rp} 13.500,00$ maka dapat dihitung nilai biaya investasi dan O\&M dari PLT Biogas yang menggunakan microturbine $250 \mathrm{~kW}$ sebagaimana Tabel 9 dan 10 .

Tabel 9 Perhitungan Biaya Investasi PLT Biogas

\begin{tabular}{lrr}
\hline \multicolumn{1}{c}{$\begin{array}{c}\text { Komponen } \\
\text { Investasi }\end{array}$} & Biaya (USD) & \multicolumn{1}{c}{ Biaya (Rp) } \\
\hline $\begin{array}{l}\text { Biogas Plant } \\
\text { Microturbine } 250\end{array}$ & 1.250 .000 & 16.875 .000 .000 \\
$k W$ & 275.000 & 3.712 .500 .000 \\
$\begin{array}{l}\text { Pengolahan limbah } \\
\& \text { Sludge }\end{array}$ & 1.551 .770 & 20.948 .895 .000 \\
\hline \multicolumn{1}{c}{ Total Biaya } & $\mathbf{3 . 0 7 6 . 7 7 0}$ & $\mathbf{4 1 . 5 3 6 . 3 9 5 . 0 0 0}$ \\
$\quad$ Investasi & & \\
\hline \multicolumn{1}{c}{ Tabel 10 Perhitungan Biaya O\&M PLT Biogas } \\
\hline Komponen O\&M & Biaya & Biaya (Rp) \\
\hline Perawatan Biogas & 61.535 & 830.722 .500 \\
Plant & & \\
Microturbine 250 & 24.700 & 333.450 .000 \\
$k W$ & 10.000 & 135.000 .000 \\
Operator (4 orang) & 5.000 & 65.000 .000 \\
Administrasi (2 & & \\
orang) & 7084 & 95.634 .000 \\
\hline Unit fuel cost & $\mathbf{1 0 8 . 3 1 9}$ & $\mathbf{1 . 4 5 9 . 8 0 6 . 5 0 0}$ \\
\hline Total Biaya O\&M & & \\
\hline
\end{tabular}

\subsubsection{Analisis Pay Back Period (PBP)}

Waktu pengembalian adalah waktu yang diperlukan (jumlah tahun) untuk mengembalikan modal investasi awal. Untuk menghitung waktu pengembalian menggunakan Persamaan 6:

$$
\begin{aligned}
\text { PBP }= & \frac{\text { Nilai Investasi Awal }}{\text { Arus Kas Tahunan }} \times 1 \text { Tahun } \\
& =\frac{\text { Nilai Investasi Awal }}{\text { Pendapatan - Pengeluaran }} \times 1 \text { Tahun } \\
& =\frac{41.536 .395 .000}{(9.863 .005 .493-1.459 .806 .500)} \times 1 \text { Tahun } \\
= & 4.94 \text { tahun } \\
& \approx 4 \text { tahun } 11 \text { bulan }
\end{aligned}
$$




\subsubsection{Analisis Net Present Value (NPV)}

Metode ini menggunakan pertimbangan bahwa nilai uang sekarang lebih tinggi bila dibandingkan dengan nilai uang pada waktu mendatang, karena adanya faktor bunga. Metode NPV merupakan metode yang dipakai untuk menilai usulan proyek investasi yang mempertimbangkan nilai waktu dari uang (time value of money). Dengan usia pembangkit 15 tahun, faktor bunga sebesar $10 \%$, pengeluaran biaya investasi awal sebesar $\mathrm{Rp}$ 41.536.395.000, jumlah pengeluaran (O\&M) pertahun Rp 1.459.806.500, dan jumlah pendapatan pertahun Rp 9.863.005.493, maka nilai NPV dapat dihitung dengan Persamaan 7 sebagaimana Tabel 11:

$$
\mathrm{NPV}=\frac{\mathrm{R}_{\mathrm{t}}}{(1+\mathrm{i})^{t}}
$$

Tabel 11. NPV untuk PLT Biogas dengan $\mathrm{i}=10 \%$

\begin{tabular}{crrrr}
\hline $\begin{array}{c}\text { tahun } \\
\text { ke }\end{array}$ & $\begin{array}{c}\text { Cash } \\
\text { Income }\end{array}$ & $\begin{array}{c}\text { Disc. } \\
\text { rate }\end{array}$ & Present Value & \multicolumn{1}{c}{$\boldsymbol{N P V}$} \\
\hline 0 & $(41.536 .395 .000)$ & 1,00 & $(41.536 .395 .000)$ & $(41.536 .395 .000)$ \\
1 & 8.403 .198 .993 & 0,91 & $7.639 .271 .811,82$ & $(33.897 .123 .188,18)$ \\
2 & 8.403 .198 .993 & 0,83 & $6.944 .792 .556,20$ & $(26.952 .330 .631,98)$ \\
3 & 8.403 .198 .993 & 0,75 & $6.313 .447 .778,36$ & $(20.638 .882 .853,62)$ \\
4 & 8.403 .198 .993 & 0,68 & $5.739 .497 .980,33$ & $(14.899 .384 .873,29)$ \\
5 & 8.403 .198 .993 & 0,62 & $5.217 .725 .436,66$ & $(9.681 .659 .436,63)$ \\
6 & 8.403 .198 .993 & 0,56 & $4.743 .386 .760,60$ & $(4.938 .272 .676,03)$ \\
7 & 8.403 .198 .993 & 0,51 & $4.312 .169 .782,37$ & $(626.102 .893,66)$ \\
8 & 8.403 .198 .993 & 0,47 & $3.920 .154 .347,61$ & $3.294 .051 .453,94$ \\
9 & 8.403 .198 .993 & 0,42 & $3.563 .776 .679,64$ & $6.857 .828 .133,59$ \\
10 & 8.403 .198 .993 & 0,39 & $3.239 .796 .981,49$ & $10.097 .625 .115,08$ \\
11 & 8.403 .198 .993 & 0,35 & $2.945 .269 .983,17$ & $13.042 .895 .098,25$ \\
12 & 8.403 .198 .993 & 0,32 & $2.677 .518 .166,52$ & $15.720 .413 .264,78$ \\
13 & 8.403 .198 .993 & 0,29 & $2.434 .107 .424,11$ & $18.154 .520 .688,89$ \\
14 & 8.403 .198 .993 & 0,26 & $2.212 .824 .931,01$ & $20.367 .345 .619,90$ \\
15 & 8.403 .198 .993 & 0,24 & $2.011 .659 .028,19$ & $22.379 .004 .648,09$ \\
\hline
\end{tabular}

Karena nilai NPV > 0 untuk tahun ke-15, maka investasi akan memberikan manfaat bagi perusahaan.

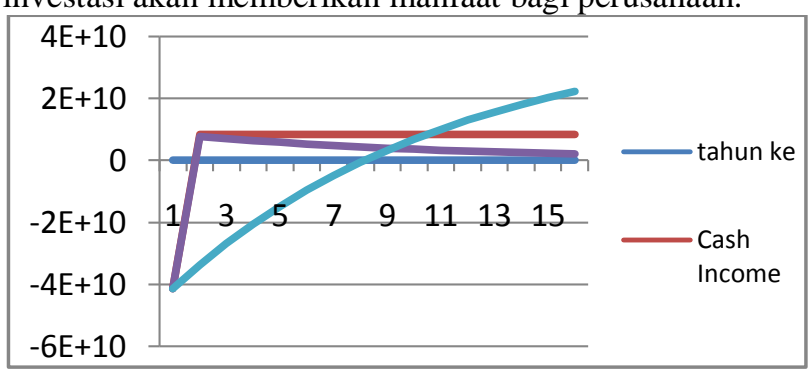

Gambar 7. Grafik NPV PLT Biogas dengan i $=10 \%$

\subsubsection{Analisis Internal Rate of Return (IRR)}

Tingkat pengembalian internal (internal rate of return-IRR) adalah tingkat bunga yang dapat menjadikan NPV sama dengan nol, karena PV arus kas pada tingkat bunga tersebut sama dengan investasi awalnya.
Tabel 12 NPV untuk PLT Biogas dengan Bunga 10\% dan 20\%

\begin{tabular}{|c|c|c|c|}
\hline $\begin{array}{c}\text { tahun } \\
\text { ke }\end{array}$ & cash income & $\begin{array}{c}\text { present value } \\
(i=10 \%)\end{array}$ & $\begin{array}{c}\text { present value } \\
\quad(i=20 \%)\end{array}$ \\
\hline 0 & $(41.536 .395 .000)$ & $(41.536 .395 .000)$ & $(41.536 .395 .000)$ \\
\hline 1 & 8.403 .198 .993 & 7.639.271.812 & 7.002 .665 .828 \\
\hline 2 & 8.403 .198 .993 & 6.944 .792 .556 & 5.835 .554 .856 \\
\hline 3 & 8.403 .198 .993 & 6.313 .447 .778 & 4.862 .962 .380 \\
\hline 4 & 8.403 .198 .993 & 5.739 .497 .980 & 4.052 .468 .650 \\
\hline 5 & 8.403 .198 .993 & 5.217 .725 .437 & 3.377 .057 .208 \\
\hline 6 & 8.403.198.993 & 4.743 .386 .761 & 2.814 .214 .340 \\
\hline 7 & 8.403 .198 .993 & 4.312 .169 .782 & 2.345 .178 .617 \\
\hline 8 & 8.403 .198 .993 & 3.920 .154 .348 & 1.954 .315 .514 \\
\hline 9 & 8.403.198.993 & 3.563 .776 .680 & 1.628.596.262 \\
\hline 10 & 8.403 .198 .993 & 3.239.796.981 & 1.357 .163 .552 \\
\hline 11 & 8.403 .198 .993 & 2.945.269.983 & 1.130 .969 .626 \\
\hline 12 & 8.403.198.993 & 2.677.518.167 & 942.474 .689 \\
\hline 13 & 8.403.198.993 & 2.434.107.424 & 785.395 .574 \\
\hline 14 & 8.403 .198 .993 & 2.212 .824 .931 & 654.496 .311 \\
\hline \multirow[t]{2}{*}{15} & 8.403.198.993 & 2.011 .659 .028 & 545.413 .593 \\
\hline & & 22.379 .004 .648 & $(2.247 .468 .000)$ \\
\hline \multicolumn{4}{|c|}{$1.0000 \mathrm{E}+11$} \\
\hline \multicolumn{4}{|c|}{$5.0000 E+10$} \\
\hline \multicolumn{4}{|c|}{$0.0000 E+00$} \\
\hline-5.0000 & $0^{910} \gamma^{0}$ & $8^{010} 2^{010} 2^{010}$ & $2^{6010} 2^{8010} 2^{010}$ \\
\hline
\end{tabular}

Gambar 8. Nilai NPV Biogas dengan IRR=18,681\%

Dengan menggunakan Persamaan 8 maka nilai IRR dapat dihitung sebagai berikut:

$$
\begin{aligned}
& I R R=i_{1}+\frac{N P V_{1}}{\left(N P V_{1}-N P V_{2}\right)}\left(i_{2}-i_{1}\right) \\
& = \\
& \left.10+\frac{22.379 .004 .648}{(22.379 .004 .648-(-2.247 .468000))} \times(20-10)\right) \\
& =18,681 \%
\end{aligned}
$$

Dari hasil analisis ekonomis yang dilakukan dengan menggunakan pay back period, net present value, dan internal rate of return maka pembangunan PLT Biogas layak untuk dilaksanakan.

\section{Kesimpulan}

Melalui proses anaerobic digestion, limbah kotoran manusia dapat dimanfaatkan sebagai bahan baku produksi biogas yang selanjutnya biogas tersebut dimanfaatkan menjadi energi utama Pembangkit Listrik Tenaga Biogas (PLT Biogas).

Dari hasil kajian teknis dan ekonomis PLT Biogas dengan memanfaatkan limbah kotoran manusia di Kota Pontianak dapat disimpulkan sebagai berikut:

- Dengan jumlah penduduk pada akhir tahun 2016 berjumlah 618.388 jiwa, dapat menghasilkan biogas dengan volume $3.091,94 \mathrm{~m}^{3} /$ hari, produksi gas metan sebesar $2.164,36 \mathrm{~m}^{3} /$ hari, potensi energi 
listrik sebesar 24.157,88 kWh/hari, dan daya listrik sebesar 1.007,33 kW

- PLT Biogas dengan menggunakan microturbine generator $250 \mathrm{~kW}$, efisiensi $30 \%$, dan power factor 0,8 menghasilkan energi listrik sebesar 5.797,9 $\mathrm{kWh} / \mathrm{hari}$ atau dengan daya 241,6 kW.

- Untuk pembangunan PLT Biogas ini diperlukan biaya investasi sebesar Rp. 41.536.395.000, biaya operasional dan pemeliharaan (O\&M) per tahun sebesar Rp. 1.459.806.500, dengan biaya pemasukan hasil penjualan listrik dan sludge/pupuk organik per tahun sebesar Rp. 9.863.005.493.

- Dari analisis ekonomi dengan tingkat suku bunga $10 \%$, dengan asumsi nilai ekonomis utilitas selama 15 tahun, diperoleh pay back period selama 4 tahun 11 bulan, net present value sebesar Rp. 22.379.004.648, dan internal rate of return sebesar $18,681 \%$, sehingga pembangunan PLT Biogas layak untuk dilaksanakan.

\section{Referensi}

[1] Peraturan Presiden Republik Indonesia Nomor 5 tahun 2006 tentang Kebijakan Energi Nasional

[2] Al Seadi, T., 2008, Biogas Handbook, University of Southern Denmark Esbjerg

[3] Badan Pusat Statistik Kota Pontianak, 2017, Kota Pontianak dalam Angka,

[4] Monet F., 2003, An Intoduction to Anaerobic Digestion of Organic Wastes (Final Report), Remade scotland

[5] Waskito, D., 2011, Analisis Pembangkit Listrik Tenaga Biogas Dengan Pemanfaatan Kotoran Sapi di Kawasan Usah Peternakan Sapi, Tesis, Universitas Indonesia

[6] Biogas Training Centre, 2014, Design of Biogas Plant, Bio-gas Project, LGED http://www.sswm.info /sites /default /files/... /BRC\%20ny\%20Design\%20Biogas\%20Plant.pdf

[7] Andriani D., et al., 2015, A Review of Recycling of Human Excreta to Energy through Biogas Generation: Indonesia case, Energy Procedia 68, pp $219-225$

[8] Sorensen B., June 2007, Renewable Energy Conversion, Transmission and Storage, Academic Press is an inprint of Elsevier

[9] Febrianto E., and Priyono S, 2012, Studi Pemanfaatan Feses (Kotoran Manusia) sebagai Bahan Baku Alternatif Energi Terbarukan, TELAAH Jurnal Ilmu Pengetahuan dan Teknologi, vol. 30, pp. 19-24

[10] Saragih, B. R., 2010, Analisis Potensi Biogas untuk Menghasilkan Energi Listrik dan Termal pada Gedung Komersil di Daerah Perkotaan (Studi Kasus pada Mal Metropolitan Bekasi), Tesis, Universitas Indonesia,
[11] Mu'azu K., 2015, Design of Biogas Plant that Uses Human Waste as Feedstock, Department of Chemical Engineering of Ahmadu Bello University, Zaria

[12] Sulistyo A., 2010, Analisis Pemanfaatan Sampah Organik di Pasar Induk Kramat Jati Sebagai Pembangkit Listrik Tenaga Biogas, Tesis, Universitas Indonesia

[13] Garcia, A. P., 2014, Techno - Economic Feasibility Study of a Small Scale Biogas Plant for Treating Market Waste in the City of El Alto, Master of Science Thesis, KTH School of Industrial Engineering and Management, Stockholm

[14] Peraturan Menteri ESDM Nomor 27 Tahun 2014 tentang Pembelian Tenaga Listrik dari Pembangkit Listrik Tenaga Biomassa dan Pembangkit ListrikTenaga Biogas oleh PT.Perusahaan Listrik Negara (Persero)

[15] Wresta, Arini,et. Al., 2015, Economic Analysis of Cow Manure Biogas as Energy Source for Electricity Power Generation in Small Scale Ranch, Energy Procedia 68, pp 122 - 131

\section{Biografi}

Ardiansyah, lahir di Pontianak pada tanggal 7 Oktober 1975, menyelesaikan pendidikan D III Teknik Elektro Program Studi Teknik Telekomunikasi dari Politeknik Universitas Diponegoro Semarang tahun 1998, menyelesaikan S1 Jurusan Teknik Elektro dari Universitas Diponegoro Semarang tahun 2002, dan menyelesaikan S2 Teknik Elektro Program Studi Manajemen Energi dari Universitas Tanjungpura Pontianak tahun 2017. Sejak tahun 2002 hingga sekarang bekerja pada Instansi Pemerintah Kota Pontianak 